\title{
ACADEMIC SELF-EFFICACY IN MILITARY HIGHER EDUCATION: ASSESSMENT OF THE PSYCHOMETRIC QUALITIES OF PERCEIVED ACADEMIC EFFICACY SCALE
}

\author{
Crenguța Mihaela MACOVEI \\ "Nicolae Bălcescu" Land Forces Academy, Sibiu, Romania \\ mihaela.macovei1@gmail.com
}

\begin{abstract}
The concept of academic self-efficacy has its origins in the social cognitive theory developed by A. Bandura and it refers to the conviction of a person that he/she can successfully achieve a certain academic goal or can solve a specific task. In this research we tested the psychometric qualities of the Perceived Academic Efficacy Scale in the context of military higher education. This scale is taken from PALS - The Patterns of Adaptive Learning Scales - and it demonstrated adequate psychometric properties that make it suitable for measuring the level of academic self-efficacy of military students. All six items on the scale load a single factor; the tested model showed a good fit.
\end{abstract}

\section{Keywords: academic self-efficacy, military students}

\section{Introduction}

The self-efficacy concept has its origin in the self-efficacy theory developed by A. Bandura. He defines perceived self-efficacy as "...people's beliefs about their capabilities to produce designated levels of performance that exercise influence over events that affect their lives."[1]. Selfefficacy beliefs significantly shape human conduct through the influence they have on four major psychological processes:

1. the cognitive processes - the influence is reflected on the amplitude of personal goals and the intensity of commitment to achieve them;

2. the motivational processes - the influence is found in the way people set their goals, the intensity of their efforts to achieve them, their perseverance and resistance to failures.

3. the affective processes - here, the self-efficacy beliefs influence control over the level of stress and anxiety felt by people while trying to achieve their goals; this control is tightly connected to selfregulation processes;

4. the selection processes - the influence is felt in the type of activities the person chooses and in the characteristics of the environment he/she prefers to live in.

A. Bandura [2] describes four major sources of self-efficacy:

- mastery experiences (successes and failures);

- vicarious experiences provided by social models;

- social persuasion;

- physiological feedback (somatic and emotional states).

Throughout a person's life, the family, the group of friends and the school provide experiences that have a major impact on self-efficacy beliefs. The school, for example, is a social setting in which all four sources of self-efficacy work to the fullest. The well-designed school activities have the effect of developing the cognitive and 
problem-solving skills of the student. The school, as well as the society, performs a continuous assessment of the level of development of these skills. Moreover, both in school and in society there is a constant process of comparing these skills. In this way children "develop a growing sense of their intellectual efficacy. Many social factors, apart from the formal instruction, such as peer modeling of cognitive skills, social comparison with the performances of other students, motivational enhancement through goals and positive incentives, and teachers interpretations of children's successes and failures in ways that reflect favorably or unfavorably on their ability also affect children's judgments of their intellectual efficacy." [3]

\section{Perceived academic efficacy}

Sharma and Nasa [4] formulated the following definition: "Academic selfefficacy refers to an individual's belief (conviction) that they can successfully achieve a designated level on an academic task or attain a specific academic goal"

Honicke and Broadbent [5] conducted a review of the researches that focused on the relationship between academic self-efficacy and university student's academic performance. Their conclusions were as follows: the analyzed studies identified (1) the moderate correlation between academic self-efficacy and academic performance, (2) the mediation and moderation effect of some significant factors, among which the most relevant are effort regulation, deep processing strategies and goal orientations. The two authors also noted that it is difficult to identify with certainty a causal relationship between the two concepts, mainly due to the lack of a longitudinal research to prove it.

Researchers studied the relationship between academic self-efficacy and academic self-concept [6] language learning motivation [7], academic performance and self-regulated learning [8], [9], [10], academic-related boredom [11], locus of control and self-concepts [12].

Perceived Academic Efficacy is a scale taken from PALS - The Patterns of Adaptive Learning Scales. As the authors state, these scales can be used together or individually [13]. PALS is an ensemble of scales created and tested over time by a group of researchers who set out to identify the relationship between students' motivation, affectivity and behavior, and the environment in which they work, starting from the assumptions of the goal orientation theory. Perceived Academic Efficacy Scale assesses "students' beliefs that they could master the material and skills taught in school if they were given enough time and exerted enough effort." [14].

Roeser, Midgley and Urdan used this scale in a study of a sample of 8th-grade middle school students. In this study the researchers identified the mediator role of variables such as personal achievement goals and feelings of school belonging in the relationship between how students perceive the psychological environment of their school and their beliefs, emotions and achievements related to school: "...perceiving a task goal structure in middle school was positively related to academic self-efficacy and this relation was mediated through personal task goals. Feelings of academic efficacy and school belonging in turn were positively related to final-semester academic grades."[15]. In their study, the Cronbach coefficient for this scale was .86 .

Kaplan and Maehr used this scale in a research through which they proposed to determine whether the way students perceive the school environment influences their well-being. One of their conclusions was as follows: "The perception that the school emphasized task goals was a positive predictor only for perceptions of academic efficacy."[16]. The two researchers reported a Cronbach coefficient of .84 for this scale. 
The PALS authors created these scales to be used at elementary school level, in the secondary school and high school. Validation studies were conducted on pupils at these educational levels. We consider, however, that the general way in which the items are formulated recommends it for use in the military university environment which, as part of the vocational education, has a particular structure that is reflected in the structure of the tasks that the students have to accomplish. In military academies, academic modules alternate with military training, and therefore students are required to make a cognitive change from the requirements of military training sessions to the requirements of academic training courses and seminars. This transition is not easy for all students; some of them are doing better in academic tasks while others solve the military instruction tasks better. Of course, there is a third category of successful students in both types of tasks. Academic self-efficacy has a situational nature - it varies depending on the field and the nature of the tasks; therefore, we believe that it is necessary to use in its measurement a tool that does not depend on the specificity of the academic task and the Perceived Academic Efficacy Scale seems to meet this requirement.

\section{Analysis}

The scale is made up of 6 items that are answered on a Likert scale made up of five anchors $(1=$ not at all true of me, $5=$ very true of me). The scale items are shown in Table 1, both in English and in Romanian language. To translate this scale we used the Forward Translation method [17].

The sample consists of 150 students of the Land Forces Academy in Sibiu, 50 students for each year ( 75 girls and 75 boys).

\begin{tabular}{|l|l|}
\hline \multicolumn{2}{|c|}{ Table 1. Perceived Academic Efficacy Scale } \\
\hline Item 1. & $\begin{array}{l}\text { I'm certain I can master the skills taught in school this year. } \\
\text { Sunt sigur(ă) ca pot să stăpânesc abilitățile predate la școală anul acesta. }\end{array}$ \\
\hline Item 2. & $\begin{array}{l}\text { Even if the work in school is hard, I can learn it. } \\
\text { Chiar dacă munca de la școală e grea, pot să o invăț. }\end{array}$ \\
\hline Item 3. & $\begin{array}{l}\text { I'm certain I can figure out how to do the most difficult school work. } \\
\text { Sunt sigur(ă) că pot să immi dau seama cum să rezolv cea mai dificilă muncă } \\
\text { școlară. }\end{array}$ \\
\hline Item 4. & $\begin{array}{l}\text { If I have enough time, I can do a good job on all my school work. } \\
\text { Dacă am destul timp, pot să fac o treabă bună în toată munca mea de la școală. }\end{array}$ \\
\hline Item 5. 5. & $\begin{array}{l}\text { I can do almost all the work in school if I don't give up. } \\
\text { Pot face aproape toată munca de la școală dacă nu renunț. }\end{array}$ \\
\hline Item 6. & $\begin{array}{l}\text { I can do even the hardest school work if I try. } \\
\text { Pot face chiar și cea mai grea muncă școlară dacă încerc. }\end{array}$ \\
\hline
\end{tabular}

To do the confirmatory factorial analysis we used Amos version 21. The applied method was Maximum Likelihood. The model is presented in Figure 1, along with the estimated parameters for our sample, which are all statistically significant $(\mathrm{p}<$ $.05)$. The six items on the scale have an acceptable level of scale loading, with factor loadings ranged from .55 to .73 .
The Cronbach's alpha for this scale is .79.

The model showed a good fit [18]: $\chi^{2}(9)=$ $16.85, \mathrm{p}=.051, \mathrm{SRMR}=.04$, RMSEA $=$ $.07, \mathrm{CFI}=.96$.

Table 2 contains the covariance matrix. Table 3 shows the relationships between items and overall score. 


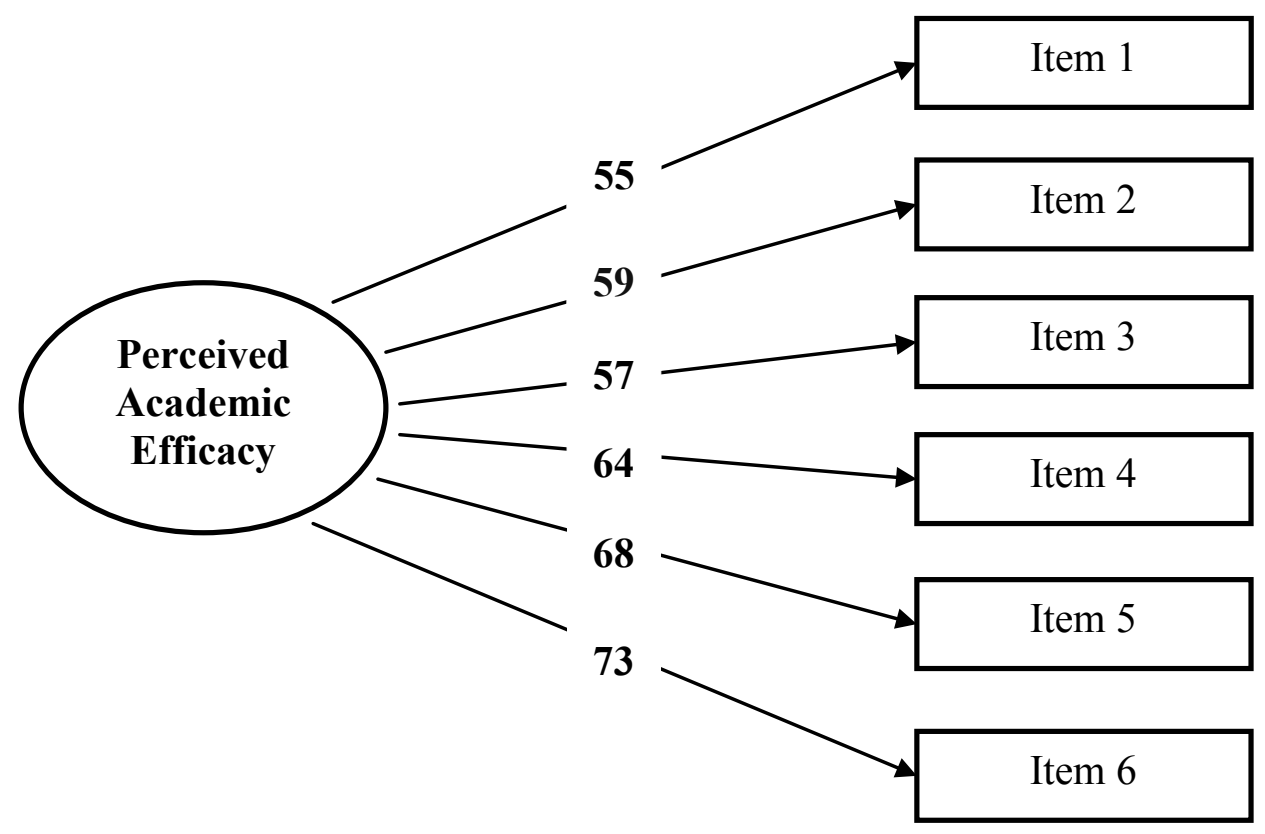

Figure 2: Single-Factor Model of the Perceived Academic Efficacy Scale $(n=150)$

Table. 2: Covariance matrix for Sample Data Set $(n=150)$

\begin{tabular}{|c|c|c|c|c|c|c|}
\hline & Item 1 & Item 2 & Item 3 & Item 4 & Item 5 & Item 6 \\
\hline Item 1. & 1.397 & & & & & \\
\hline Item 2. & .647 & 1.356 & & & & \\
\hline Item 3. & .587 & .475 & 1.066 & & & \\
\hline Item 4. & .461 & .479 & .389 & .957 & & \\
\hline Item 5. & .587 & .528 & .443 & .184 & 1.100 & \\
\hline Item 6. & .477 & .480 & .329 & .426 & .313 & 1.090 \\
\hline
\end{tabular}

Table 3. Item Total Statistic $(n=150)$

\begin{tabular}{|c|c|c|c|c|}
\hline & $\begin{array}{c}\text { Scale Mean if } \\
\text { Item Deleted }\end{array}$ & $\begin{array}{c}\text { Scale Variance if } \\
\text { Item Deleted }\end{array}$ & $\begin{array}{c}\text { Corrected Item- } \\
\text { Total Correlation }\end{array}$ & $\begin{array}{c}\text { Cronbach's Alpha } \\
\text { if Item Deleted }\end{array}$ \\
\hline Item 1. & 27.25 & 15.543 & .493 & .774 \\
\hline Item 2. & 27.08 & 15.470 & .500 & .773 \\
\hline Item 3. & 27.46 & 15.847 & .500 & .773 \\
\hline Item 4. & 26.88 & 15.167 & .555 & .760 \\
\hline Item 5. & 27.17 & 14.100 & .599 & .749 \\
\hline Item 6. & 27.33 & 13.754 & .632 & .740 \\
\hline
\end{tabular}

\section{Conclusion}

This research tested the psychometric qualities of the Perceived Academic Efficacy Scale in the context of military higher education. The scale demonstrated adequate psychometric properties that make it suitable for measuring the level of academic self-efficacy of military students. In the activities that students perform, they are affected by personal and situational 
factors that influence their results and provide feedback on their own self-efficacy. It is the duty of the school and teachers to create a learning environment that stimulates the development of students' cognitive abilities and an climate that facilitates the emergence and maintenance of an optimistic attitude towards the possibility of academic success. Students' confidence in their ability to succeed in academic tasks will influence their level of involvement in this type of activities, their aspirations, interest and lifelong learning. According to Bandura [19], students' selfefficacy can be developed if the school creates personalized classroom structures and offers individualized training, tailored to each student's needs and knowledge level.

\section{References}

[1] Bandura, A., Self-efficacy. In V. S. Ramachaudran (Ed.), Encyclopedia of human behavior (Vol. 4, pp. 71-81). New York: Academic Press. (Reprinted in H. Friedman [Ed.], Encyclopedia of mental health. San Diego: Academic Press, 1998, p. 2

[2] ibidem, p. 2-3

[3] ibidem, p. 11

[4] Sharma, H.L., Nasa, G., Academic Self-Efficacy: A Reliable Predictor Of Educational Performances, British Journal of Education, Vol. 2, No. 3, pp. 57-64, 2014, p. 59.

[5] Honicke, T., Broadbent, J., The influence of academic self-efficacy on academic performance: A systematic review. Educational Research Review, Vol. 17, pp. 63-84, 2016.

[6] Ferla, J., Valke, M., Cai, Y., Academic self-efficacy and academic self-concept: Reconsidering structural relationships. Learning and Individual Differences, Vol. 19, Issue 4, pp. 499-505, 2009. https://doi.org/10.1016/j.lindif.2009.05.004

[7] Ersanli, C.Y., The relationship between students' academic self-efficacy and language learning motivation: A study of 8th graders, Procedia - Social and Behavioral Sciences, 199 (2015), pp. 472 - 478, 2015.

[8] Alyami, M., Melyani, Z., Al Johani, A., Ullah, E., Alyami, H., Sundram, F., Hill, A., Henning, M., The Impact of Self-Esteem, Academic Self-Efficacy and Perceived Stress on Academic Performance: A Cross-Sectional Study of Saudi Psychology Students, European Journal of Educational Sciences (EJES), Vol. 4, No. 3, pp. 51-68, 2017. doi: 10.19044/ejes.v4no3a5URL:http://dx.doi.org/10.19044/ejes.v4no3a5

[9] Alegre, A., Academic self-efficacy, self- regulated learning and academic performance in first-year university students. Propósitos y Representaciones, 2(1), pp. 79-120, 2014. doi: http://dx.doi.org/10.20511/pyr2014.v2n1.54

[10] Meral, M., Colak, E., Zereyak, E., The Relationship between Self-Efficacy and Academic Performance, Procedia - Social and Behavioral Sciences, Vol. 46, pp. 11431146, 2012. https://doi.org/10.1016/j.sbspro.2012.05.264.

[11] Liu, Y., Lu, Z., The Relationship between Academic Self-Efficacy and AcademicRelated Boredom: MAOA Gene as a Moderator, Youth \& Society, Vol. 49, Issue 2, pp. 254 - 267, 2014, https://doi.org/10.1177/0044118X14535219

[12] Sagone, E., De Caroli, M. E., Locus of control and academic self-efficacy in university students: the effects of Self-concepts, Procedia - Social and Behavioral Sciences 114, 2014, pp. 222-228, 2014. https://www.sciencedirect.com/science/article/pii/S1877042813053287

[13] Midgley, C., Maehr, M.L., Hruda, L.Z., Anderman, E., Anderman, L., Freeman, K.E., Gheen, M., Kaplan, A., Kumar, R.., Middleton, M.J., Nelson, J., Roeser, R., Urdan, T., Manual for the Patterns of Adaptive Learning Scales, University of Michigan, 2000. http://www.umich.edu/ pals/PALS\%202000_V13Word97.pdf 
[14] Roeser, R. W., Midgley, C., Urdan, T. C., Perceptions of the school psychological environment and early adolescents' psychological and behavioral functioning in school: The mediating role of goals and belonging. Journal of Educational Psychology, 88, pp. 408-422, 1996, p. 413.

[15] ibidem, p .408

[16] Kaplan, A., Maehr, M.L, Achievement Goals and Student Well-Being, Contemporary Educational Psychology, 24, pp. 330-358, 1999. Article ID ceps.1999.0993, available online at http://www.idealibrary.com on, http://condor.depaul.edu/hstein/NALPAK.pdf, p. 346

[17] International Test Commission. The ITC Guidelines for Translating and Adapting Tests (Second edition), 2016.www.InTestCom.org

[18] Hooper, D., Coughlan, J., Mullen, M.R, Structural Equation Modelling: Guidelines for Determining Model Fit, The Electronic Journal of Business Research Methods, Vol. 6, Issue 12008 , pp. 53-60, available online at www.ejbrm.com

[19] Bandura, A., op.cit., p. 12 